\title{
Response of Bell Pepper (Capsicum annum L. var. grossum) to Drip Irrigation Levels and Black Plastic Mulch under Naturally Ventilated Polyhouse
}

\author{
Sajal Debbarma*, Lalit Bhatt and S. P. Uniyal \\ Department of Vegetable Science, Govind Ballabh Pant University of Agriculture and \\ Technology, Pantnagar, Uttarakhand, India \\ *Corresponding author
}

\section{A B S T R A C T}

Keywords

Drip irrigation,

Crop water requirement, Black plastic mulch, Bell pepper, Water-use efficiency

\section{Article Info}

Accepted:

04 September 2019 Available Online: 10 October 2019
A study was conducted to quantify the effects of drip irrigation levels and black plastic mulch on bell pepper production under a naturally ventilated polyhouse in Tarai region of Uttarakhand during Rabi 2014-15.The experiment was laid out in randomized block design with three replications keeping four drip irrigation levels $(100,80,60$ and $40 \%$ of crop water requirement) and surface irrigation in conjunction with black plastic mulch and without mulch. It was observed that plant morphological parameters viz. plant height, fresh and dry weight of plant and root and fruit characters such as number of fruits per plant, average fruit weight, fruit length \&diameter, polar \& lateral circumstances of fruit and total yield were significantly increased by drip irrigation alone as well as in conjunction with black plastic mulch. Drip irrigation at $80 \%$ of crop water requirement gave the highest yield of fruits $(83.22 \mathrm{t} / \mathrm{ha})$, whereas it was the least $(66.99 \mathrm{t} / \mathrm{ha})$ in case of surface irrigation. The yield was further increased by the use of black polyethylene mulch $(88.99$ t/ha).It was also observed that drip irrigation both with and without plastic mulch registered much higher water use efficiency (WUE) compared to surface irrigation. The minimum water use efficiency of $142.4 \mathrm{~kg} \mathrm{ha}^{-1} \mathrm{~mm}^{-1}$ was obtained for the plots receiving surface irrigation without the mulch. The use of black film in case of surface irrigation increased the WUE to $163.2 \mathrm{~kg} \mathrm{ha}^{-1} \mathrm{~mm}^{-1}$.

\section{Introduction}

Bell pepper (Capsicum annum L. var. grossum) is a popular vegetable of the family Solanaceae. It is mainly grown in India during cooler part of the year (autumn-winter) when air temperatures are moderate (Singh et al.,
1993). It is a successful off season vegetable of Himachal Pradesh, Jammu and Kashmir, Uttarakhand, Nilgiri hills (Tamil Nadu) and Darjeeling district of West Bengal during summer- rainy months and autumn crop of Madhya Pradesh, Uttar Pradesh, Jharkhand, Maharashtra (Pune and Thane districts) and 
Karnataka (Bangalore, Belgaum and Mysore districts). Bell pepper has both nutritional and nutraceutical importance; it contains an anticoagulant that helps in preventing the blood clots and reduces the risk of heart attack (Nadeem et al., 2011).

Water is one of the most important inputs for the successful crop production. Water management in bell pepper is extremely important assoil moisture stress during the growing period reduces the yield and quality. Besides, water also contributes to the cooling of plants during the period of high temperature. In present conditions, water has become scarce natural resource due to rapid population growth, industrialization, urbanization and erratic rainfall. This is not only causing global warming but irrigation water is also becoming both scarce and expensive due to fast depletion of surface and sub-surface water resources. Hence, to achieve sustainable higher returns per unit area judicious use of irrigation water through drip system along with plastic mulch in naturally ventilated polyhouse has become inevitable. Keeping in view the above concerns the present investigation of drip irrigation levels and black plastic mulch on capsicum production under naturally ventilated polyhouse" was undertaken during the rabi season of 2014-15 under the agro-climatic condition of Tarai region of Uttarakhand, India.

\section{Materials and Methods}

The study was undertaken at Vegetable Research Centre of G.B. Pant University of Agriculture and Technology, Pantnagar (Uttarakhand), India during Rabi cropping season from September 2014 to May 2015.The experiment consisting of 10 treatments was laid out in randomized block design with three replications. The treatment details are given in the table below. The volume of water for $100 \%$ crop water requirement based on pan evaporation was computed using the following equation (Allen et al., 1998)

$\mathrm{V}=\mathrm{Ep} \times \mathrm{Kp} \times \mathrm{Kc} \times \mathrm{Sp} \times \mathrm{Sr} \times \mathrm{Wp}$

Where, $\mathrm{V}=$ Water requirement of plant per day (1), $\mathrm{Ep}=\mathrm{PAN}$ evaporation, $\mathrm{Kp}=\mathrm{Pan}$ Coefficient, $\mathrm{Kc}=\mathrm{Crop}$ coefficient varies according to growth, $\mathrm{Sp}=$ Plant to plant spacing (m), Sr=Row to Row spacing (m), $\mathrm{W} p=$ Fraction wetted area

The experiment was carried out in a medium cost naturally ventilated polyhouse of $100 \mathrm{~m}^{2}$ area. The polyhouse was not equipped with any heating or cooling system and the side walls of the polyhouse was covered with insect proof net to prevent the entry of insect pests. Before transplanting the seedlings, the experimental field was well prepared with the help of spade followed by breaking of clods and levelling. After levelling, the field was divided into plots with walking strips in between the plots. After field preparation 15 $\mathrm{cm}$ raised beds of $150 \mathrm{~cm}$ width were made and over these, black plastic mulch of 40 micron thickness was spread according to the treatments and their corners and sides were covered with soil. Holes were made at a spacing of $60 \times 50 \mathrm{~cm}$ for easy transplanting of seedlings. Healthy seedlings of capsicum cv. Indira were transplanted in the polyhouse on $17^{\text {th }}$ October, 2014. Once the seedlings were established, all the necessary recommended cultural and plant protection practices were followed. Observations were recorded for plant height, days to 50 percent flowering, days to first picking, number of fruits per plant, fruit length $(\mathrm{cm})$, fruit diameter $(\mathrm{cm})$, fruit polar circumference $(\mathrm{cm})$, fruit lateral circumference $(\mathrm{cm})$ and fruit yield using standard methods. After the final harvest, the plants were dug out and the dry weight of shoot (stem and leaves) and root 
were determined after complete drying at $60^{\circ} \mathrm{C}$. The water use efficiency was computed by dividing the yield with water requirement of the crop.

\section{Soil data}

To characterize the soil at experimental plot, the soil of experimental field was analyzed for the physical and chemical properties by collecting a composite soil sample from $0-15 \mathrm{~cm}$ soil depth before transplanting of seedlings (Fig. 1). The soil test values are given in Table 2 .

\section{Results and Discussion}

\section{Growth characters}

Data in Table 3 for plant growth parameters indicate that drip irrigation, with or without mulch had significantly increased the plant height, fresh and dry weight of plant and root compared to surface irrigation. The maximum plant height of $108.30 \mathrm{~cm}$, fresh $(591.050 \mathrm{~g})$ and dry (178.72 g) weight as well as fresh $(55.08 \mathrm{~g})$ and dry weight $(15.78 \mathrm{~g})$ of root at final stage of crop were recorded in treatment $\mathrm{T}_{4}$ (80 percent water requirement with black plastic mulch) followed by irrigation at 60 percent water requirement under mulched condition $\left(\mathrm{T}_{6}\right)$. The minimum values for these three plant parameters were obtained in treatment receiving surface irrigation without use of mulch $\left(\mathrm{T}_{9}\right)$. It is noticed that increasing and decreasing the irrigation volume above and below 80 percent of crop water requirement significantly reduced the plant height, fresh and dry weight of plant and root. Significant improvement in plant growth parameters was also noticed by the use of plastic mulch. With respect to root length, minimum length of $16.01 \mathrm{~cm}$ was measured at 100 percent drip irrigation level without mulch condition and thereafter it gradually increased to $23.30 \mathrm{~cm}$ under mulched condition with the reduction in irrigation volume up to 40 percent.
The higher plant height, fresh and dry weight of plant under drip irrigation could be attributed to vigorous growth of plants due to better absorption and uptake of plant nutrients under optimum soil moisture range. Similarly, increase in growth characters in plastic mulched plots might be due to capabilities of mulch to maintain thermo-moisture regime in the soil which increased efficiency of water uptake by plants. These results are in conformity with the findings of Singh et al., (2009). The more root weight due to increase in irrigation level might be attributed due to frequent and consistent application of water in the vicinity of the roots, which provides better soil moisture regime in the crop root zone throughout the crop growth period. Osmotic adjustment and prolonging root cell expansion might be the reasons for increased root length in mildly stressed plants than well-watered plants and the roots go deeper for the uptake of nutrients (Sharp et al., 2009). These observations are in conformity with the findings of Antony and Singandhupe (2004). The more root length under plastic mulching could be attributed because of favourable influence of soil moisture and temperature. Wien et al., (1993) also found significantly longer roots in mulched tomato as compared to the unmulched tomato.

\section{Maturity}

Drip irrigation levels and black plastic mulch had shown significant impact on days to 50 percent flowering and days to first fruit picking (Table 3 ). The minimum number of days (38.42) to 50 percent flowering was noticed in the treatment receiving 40 percent irrigation and using black plastic mulch. In contrast, plants receiving 100 percent irrigation water without the use of black plastic mulch took the maximum days (43.01) for achieving 50 percent flowering. Treatment $\mathrm{T}_{8}$ (40 percent water through drip and use of black plastic mulch) resulted into the earliest 
fruit picking which was statistically at par with $\mathrm{T}_{5}$ (54.31 days). Maximum days (55.34) for first fruit picking were taken for $T_{1} T_{2}$ and $\mathrm{T}_{9}$ being statistically same as $\mathrm{T}_{1}$. Black plastic mulch advanced the flowering and harvesting time of capsicum fruits compared to unmulched condition.

Delay in flowering and harvesting with increasing irrigation volume could be attributed to the increased vegetable growth at higher soil moisture levels which ultimately delayed the reproductive phase. This result is in agreement with the findings of Lodhi et al., (2014). Earliness in flowering and harvesting under low irrigation volume could be attributed to the low availability of water at optimum level for growth and development which possess mild moisture stress than wellwatered plants and under such conditions plants tend to shorten their life span and enter into reproductive phase faster.

These results are in agreement with the findings of Antony and Singandhupe (2004).
Optimum soil temperature and better microclimate under plastic mulch lead to early growth and development with advanced flowering and fruit setting (Bhatt et al., 2011).

\section{Fruit characters}

Significant differences for fruit number per plant of capsicum were observed in mulched and unmulched treatments and also among various levels of drip irrigation under naturally ventilated polyhouse (Table 4).

Maximum number of fruits per plant (28.60) was obtained in treatment $\mathrm{T}_{4}$ (Irrigation at 80 percent of crop water requirement along with black plastic mulch) followed by irrigation at 60 percent irrigation along with black plastic mulch $\left(\mathrm{T}_{6}\right)$. Fruit number was found to be the minimum (21.18) in $\mathrm{T}_{9}$. Use of plastic mulch and 80 percent of irrigation volume increased the fruits per plant by $35 \%$ over the unmulched plot with surface irrigation $\left(\mathrm{T}_{9}\right)$.

Table.1 Details of treatments are given below

\begin{tabular}{|c|c|}
\hline Treatments & Specifications \\
\hline $\mathbf{T}_{\mathbf{1}}$ & Irrigation at 100\% crop water requirement without black plastic mulch \\
\hline $\mathbf{T}_{\mathbf{2}}$ & Irrigation at 100\% crop water requirement with black plastic mulch \\
\hline $\mathbf{T}_{\mathbf{3}}$ & Irrigation at 80\% crop water requirement without black plastic mulch \\
\hline $\mathbf{T}_{\mathbf{4}}$ & Irrigation at $80 \%$ crop water requirement with black plastic mulch \\
\hline $\mathbf{T}_{\mathbf{5}}$ & Irrigation at 60\% crop water requirement without black plastic mulch \\
\hline $\mathbf{T}_{\mathbf{6}}$ & Irrigation at 60\% crop water requirement with black plastic mulch \\
\hline $\mathbf{T}_{\mathbf{7}}$ & Irrigation at 40\% crop water requirement without black plastic mulch \\
\hline $\mathbf{T}_{\mathbf{8}}$ & Irrigation at 40\% crop water requirement with black plastic mulch \\
\hline $\mathbf{T}_{\mathbf{9}}$ & Surface irrigation without black plastic mulch \\
\hline $\mathbf{T}_{\mathbf{1 0}}$ & Surface irrigation with black plastic mulch \\
\hline
\end{tabular}


Table.2 Physico- chemical composition of soil of the experimental plot

\begin{tabular}{|c|c|c|c|}
\hline SI. No. & Characters & $\begin{array}{c}\text { Values } \\
\text { obtained } \\
\text { Sandy- loam }\end{array}$ & Method of analysis followed \\
\hline $\mathbf{1 .}$ & Texture & 7.15 & $\begin{array}{c}\text { Feeling method } \\
\text { Glass electrode method } \\
\text { (Jackson, 1967) }\end{array}$ \\
\hline $\mathbf{2 .}$ & $\mathrm{pH}$ & 145.2 & $\begin{array}{c}\text { Alkaline } \mathrm{KMnO}_{4}(\text { Subbiah and } \\
\text { Asija, 1956) }\end{array}$ \\
\hline $\mathbf{3 .}$ & Available nitrogen $(\mathrm{kg} / \mathrm{ha})$ & 20.78 & $\begin{array}{c}\text { Olsen's method (Olsen } \text { et al., } \\
\text { 1967) }\end{array}$ \\
\hline $\mathbf{4 .}$ & $\begin{array}{c}\text { Available phosphorus } \\
\text { (kg/ha) }\end{array}$ & 126.01 & $\mathrm{NH}_{4}$ OAc (Pratt, 1965) \\
\hline $\mathbf{5 .}$ & Available potash (kg/ha) & 0.90 & $\begin{array}{c}\text { Titration method (Walkey and } \\
\text { Black, 1934) }\end{array}$ \\
\hline $\mathbf{6 .}$ & \begin{tabular}{c} 
Organic carbon $(\%)$ \\
\hline
\end{tabular} & & \\
\hline
\end{tabular}

Table.3 Effect of drip irrigation levels and black plastic mulch on plant growth characters and maturity of capsicum under naturally ventilated polyhouse

\begin{tabular}{|c|c|c|c|c|c|c|c|c|c|c|c|}
\hline \multirow[t]{2}{*}{$\begin{array}{c}\text { Treatme } \\
\text { nts }\end{array}$} & \multicolumn{4}{|c|}{ Plant height (cm) } & \multirow{2}{*}{$\begin{array}{c}\text { Days } \\
\text { to } \\
50 \% \\
\text { flowe } \\
\text { ring }\end{array}$} & \multirow{2}{*}{$\begin{array}{l}\text { Days to } \\
\text { first } \\
\text { fruit } \\
\text { picking }\end{array}$} & \multicolumn{2}{|c|}{ Weight/plant (g) } & \multicolumn{2}{|c|}{$\begin{array}{c}\text { Root } \\
\text { weight/plant (g) }\end{array}$} & \multirow{2}{*}{$\begin{array}{l}\text { Root } \\
\text { length } \\
\text { (cm) }\end{array}$} \\
\hline & $\begin{array}{c}45 \\
\text { DAT }\end{array}$ & $\begin{array}{c}90 \\
\text { DAT }\end{array}$ & $\begin{array}{c}135 \\
\text { DAT }\end{array}$ & $\begin{array}{l}\text { Final } \\
\text { stage }\end{array}$ & & & Fresh & Dry & Fresh & Dry & \\
\hline$T_{1}$ & 55.77 & 62.73 & 68.45 & 95.17 & 43.01 & 55.34 & 481.35 & 149.69 & 43.22 & 11.86 & 16.01 \\
\hline $\mathbf{T}_{2}$ & 56.44 & 63.73 & 71.15 & 96.51 & 42.12 & 55.12 & 518.18 & 158.05 & 45.75 & 12.07 & 16.15 \\
\hline $\mathbf{T}_{3}$ & 56.10 & 62.63 & 71.08 & 102.47 & 42.10 & 55.01 & 524.34 & 158.33 & 50.41 & 14.36 & 17.58 \\
\hline $\mathbf{T}_{4}$ & 58.24 & 65.97 & 75.15 & 108.30 & 40.15 & 54.04 & 591.05 & 178.72 & 55.08 & 15.78 & 17.62 \\
\hline$T_{5}$ & 55.53 & 63.87 & 70.68 & 100.07 & 42.02 & 54.31 & 504.01 & 150.06 & 46.03 & 11.86 & 17.64 \\
\hline$T_{6}$ & 57.11 & 64.37 & 73.20 & 101.70 & 40.08 & 53.15 & 556.70 & 164.37 & 50.10 & 14.01 & 18.01 \\
\hline $\mathbf{T}_{7}$ & 54.48 & 60.35 & 66.28 & 92.12 & 40.05 & 54.02 & 417.37 & 131.04 & 42.32 & 10.75 & 22.14 \\
\hline $\mathbf{T}_{8}$ & 54.84 & 61.07 & 66.84 & 93.83 & 38.42 & 53.06 & 428.12 & 141.91 & 43.65 & 10.90 & 23.30 \\
\hline $\mathbf{T}_{\mathbf{9}}$ & 52.14 & 57.03 & 63.41 & 88.83 & 41.80 & 55.08 & 411.36 & 128.64 & 40.36 & 10.67 & 20.19 \\
\hline$T_{10}$ & 52.06 & 58.28 & 66.72 & 90.32 & 41.00 & 55.04 & 454.70 & 139.00 & 43.19 & 11.63 & 21.23 \\
\hline $\begin{array}{c}\text { CD at } \\
5 \%\end{array}$ & 1.18 & 3.23 & 2.66 & 3.44 & 0.71 & 0.32 & 36.31 & 9.41 & 1.57 & 1.34 & 0.68 \\
\hline
\end{tabular}


Table.4 Effect of drip irrigation levels and black plastic mulch on fruit characters of capsicum under naturally ventilated polyhouse

\begin{tabular}{|c|c|c|c|c|c|c|c|c|c|c|c|c|c|c|c|c|c|c|c|}
\hline \multirow[t]{2}{*}{$\begin{array}{l}\text { Treat } \\
\text { ments }\end{array}$} & \multirow{2}{*}{$\begin{array}{c}\text { Number } \\
\text { of fruits } \\
\text { per } \\
\text { plant }\end{array}$} & \multicolumn{4}{|c|}{ Fruit length $(\mathrm{cm})$} & \multicolumn{4}{|c|}{ Fruit diameter (cm) } & \multicolumn{4}{|c|}{$\begin{array}{c}\text { Fruit polar circumference } \\
(\mathbf{c m})\end{array}$} & \multicolumn{4}{|c|}{$\begin{array}{l}\text { Fruit lateral circumference } \\
(\mathbf{c m})\end{array}$} & \multirow{2}{*}{$\begin{array}{l}\text { Average } \\
\text { dry matter } \\
\text { content of } \\
\text { fruit }(\%)\end{array}$} & \multirow{2}{*}{$\begin{array}{l}\text { Fruit } \\
\text { weigh } \\
\text { (g) }\end{array}$} \\
\hline & & $\begin{array}{l}2^{\text {nd }} \\
\text { pickin } \\
\mathrm{g}\end{array}$ & $\begin{array}{c}4^{\text {th }} \\
\text { picki } \\
\text { ng }\end{array}$ & $\begin{array}{c}6^{\text {th }} \\
\text { picki } \\
\text { ng }\end{array}$ & $\begin{array}{c}8^{\text {th }} \\
\text { picki } \\
\text { ng }\end{array}$ & $\begin{array}{l}2^{\text {nd }} \\
\text { pickin } \\
\text { g }\end{array}$ & $\begin{array}{l}4^{\text {th }} \\
\text { pickin } \\
\text { g }\end{array}$ & $\begin{array}{c}6^{\text {th }} \\
\text { pickin } \\
\text { g }\end{array}$ & $\begin{array}{l}8^{\text {th }} \\
\text { picki } \\
\text { ng }\end{array}$ & $\begin{array}{l}2^{\text {nd }} \\
\text { pickin } \\
\text { g }\end{array}$ & $\begin{array}{l}4^{\text {th }} \\
\text { pickin } \\
\text { g }\end{array}$ & $\begin{array}{c}6^{\text {th }} \\
\text { pickin } \\
\text { g }\end{array}$ & $\begin{array}{l}8^{\text {th }} \\
\text { picking }\end{array}$ & $\begin{array}{c}2^{\text {nd }} \\
\text { picki } \\
\text { ng }\end{array}$ & $\begin{array}{c}4^{\text {th }} \\
\text { picki } \\
\text { ng }\end{array}$ & $\begin{array}{c}6^{\text {th }} \\
\text { picki } \\
\text { ng }\end{array}$ & $\begin{array}{c}8^{\text {th }} \\
\text { picki } \\
\text { ng }\end{array}$ & & \\
\hline$T_{1}$ & 24.44 & 7.15 & 6.70 & 6.40 & 5.32 & 5.94 & 6.15 & 6.22 & 6.23 & 17.50 & 16.66 & 19.51 & 19.13 & 19.12 & 19.46 & 20.60 & 20.23 & 6.69 & 94.70 \\
\hline$T_{2}$ & 26.25 & 7.35 & 7.15 & 6.82 & 5.65 & 6.06 & 6.52 & 6.55 & 6.30 & 17.92 & 17.19 & 19.72 & 19.24 & 20.15 & 19.67 & 21.07 & 20.39 & 7.10 & 94.83 \\
\hline $\mathbf{T}_{3}$ & 26.57 & 7.52 & 6.97 & 6.92 & 6.15 & 6.82 & 6.40 & 6.80 & 6.45 & 17.92 & 18.20 & 20.47 & 19.21 & 19.87 & 20.16 & 21.97 & 20.14 & 7.02 & 95.56 \\
\hline $\mathbf{T}_{4}$ & 28.60 & 7.72 & 7.22 & 7.15 & 6.82 & 7.12 & 6.76 & 7.08 & 6.57 & 18.42 & 18.49 & 23.45 & 21.17 & 21.00 & 20.76 & 24.22 & 22.62 & 7.18 & 98.04 \\
\hline$T_{5}$ & 25.83 & 7.30 & 6.92 & 6.72 & 5.57 & 5.97 & 6.27 & 6.75 & 6.25 & 18.10 & 17.92 & 21.09 & 19.82 & 19.70 & 19.91 & 22.10 & 20.51 & 7.20 & 94.94 \\
\hline$T_{6}$ & 27.10 & 7.52 & 7.15 & 7.12 & 5.75 & 6.82 & 6.55 & 6.97 & 6.51 & 18.18 & 18.10 & 22.03 & 19.57 & 19.97 & 20.17 & 23.37 & 21.22 & 7.24 & 95.12 \\
\hline $\mathbf{T}_{7}$ & 23.41 & 6.37 & 6.37 & 6.55 & 5.45 & 5.80 & 5.99 & 6.21 & 6.07 & 17.17 & 16.67 & 19.23 & 18.98 & 19.30 & 19.36 & 20.12 & 17.71 & 7.20 & 93.52 \\
\hline$T_{8}$ & 26.25 & 6.72 & 6.61 & 6.67 & 5.60 & 5.93 & 6.02 & 6.37 & 6.12 & 17.50 & 17.12 & 19.22 & 19.14 & 19.52 & 19.49 & 20.61 & 19.80 & 7.49 & 94.19 \\
\hline $\mathbf{T}_{9}$ & 21.18 & 6.25 & 6.20 & 6.20 & 5.16 & 5.62 & 5.85 & 6.12 & 6.00 & 16.97 & 16.53 & 19.05 & 18.76 & 19.16 & 19.14 & 19.48 & 19.03 & 7.32 & 90.09 \\
\hline$T_{10}$ & 23.45 & 6.53 & 6.48 & 6.48 & 5.25 & 5.82 & 5.95 & 6.15 & 6.06 & 17.10 & 16.95 & 19.06 & 19.04 & 19.23 & 19.20 & 20.14 & 19.37 & 7.43 & 92.35 \\
\hline $\begin{array}{l}\text { CD at } \\
5 \%\end{array}$ & 1.29 & 0.28 & 0.21 & 0.28 & 0.32 & 0.25 & 0.16 & 0.28 & 0.17 & 0.49 & 0.45 & 0.79 & 0.33 & 0.82 & 0.52 & 0.96 & 0.83 & NS & 4.30 \\
\hline
\end{tabular}

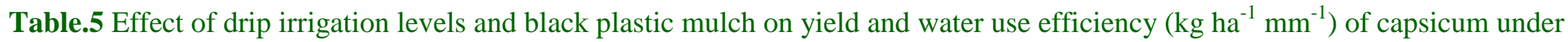
naturally ventilated polyhouse

\begin{tabular}{|c|c|c|c|}
\hline Treatments & $\begin{array}{c}\text { Average yield/ plant } \mathbf{( k g )} \\
\text { Average yield/ha (t) }\end{array}$ & $\begin{array}{c}\text { Water use efficiency } \\
\left(\mathbf{k g} \mathbf{~ h a}^{-\mathbf{1}} \mathbf{m m}^{-\mathbf{1}} \mathbf{)}\right.\end{array}$ \\
\hline $\mathbf{T}_{\mathbf{1}}$ & 2.42 & 80.66 & 171.4 \\
\hline $\mathbf{T}_{\mathbf{2}}$ & 2.60 & 86.66 & 184.2 \\
\hline $\mathbf{T}_{\mathbf{3}}$ & 2.50 & 83.22 & 221.1 \\
\hline $\mathbf{T}_{\mathbf{4}}$ & 2.67 & 88.99 & 236.4 \\
\hline $\mathbf{T}_{\mathbf{5}}$ & 2.47 & 82.44 & 292.1 \\
\hline $\mathbf{T}_{\mathbf{6}}$ & 2.64 & 87.88 & 311.4 \\
\hline $\mathbf{T}_{\mathbf{7}}$ & 2.33 & 77.66 & 412.8 \\
\hline $\mathbf{T}_{\mathbf{8}}$ & 2.47 & 82.33 & 437.6 \\
\hline $\mathbf{T}_{\mathbf{9}}$ & 2.01 & 66.99 & 142.4 \\
\hline $\mathbf{T}_{\mathbf{1 0}}$ & 2.30 & 76.77 & \\
\hline $\mathbf{C D}$ at 5\% & 0.79 & 2.66 & 163.2 \\
\hline
\end{tabular}


Fig.1 View of experimental site

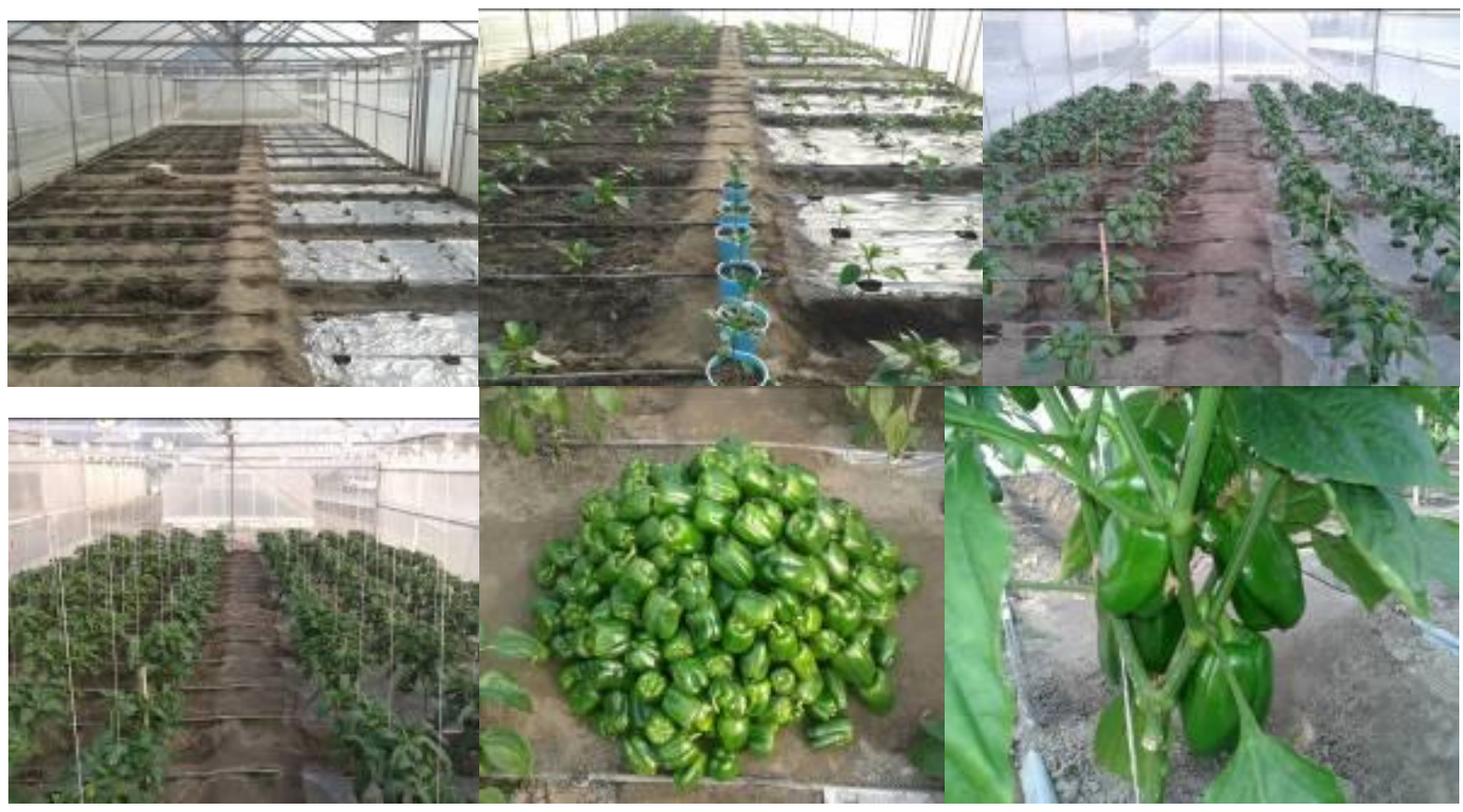

Maximum fruit length \& diameter and polar \& lateral circumstances of fruits were also recorded for treatment $\mathrm{T}_{4}$. The maximum fruit length of $7.72 \mathrm{~cm}$ and fruit diameter of 7.12 $\mathrm{cm}$ were measured at $2^{\text {nd }}$ picking. Fruit length was found to be decreasing gradually in the subsequent pickings.

The trend was just opposite for fruit diameter. The maximum fruit polar circumference of $23.45 \mathrm{~cm}$ was measured at $6^{\text {th }}$ picking and thereafter it showed decreasing trend up to $8^{\text {th }}$ picking $(21.17 \mathrm{~cm})$. Similar to polar circumference, maximum lateral fruit circumference of $24.22 \mathrm{~cm}$ was noted at $6^{\text {th }}$ picking in $\mathrm{T}_{4}$. The same treatment had also shown maximum average fruit weight of $98.40 \mathrm{~g}$. So far fruit dry matter content is concerned, it showed non-significant impact under. Besides deficit irrigation in the study in plants increased the dry matter content of fruit.

Increase in number of fruits at 80 percent water requirement could be due to availability of just sufficient soil moisture which enhanced photosynthetic area and better partitioning of dry matter ultimately leading to the positive effects on growth parameters (Choudhary and Bhambri, 2012).

The increase in fruit length, diameter, polar and lateral circumference under drip irrigation may be attributed to the frequent and consistent application of water in the vicinity of the roots which provide better soil moisture regime in the crop root zone throughout the crop growth. These results are in agreement with the findings of Sezen et al., (2006) in bell pepper.

All the fruit characters were found to be increased in the treatments having black plastic mulch as those without mulch. Nagalakshmi et al., (2002) also obtained the maximum length and diameter of fruits in chilli with the application of black plastic mulch.

\section{Yield}

The data on fruit yield of capsicum in Table 5 indicate that drip irrigation had significant 
impact on fruit yield over surface irrigation, with or without mulching. The maximum yield of fruits per plant of $2.67 \mathrm{~kg}$ and total yield of $88.99 \mathrm{t} / \mathrm{ha}$ were obtained in treatment $\mathrm{T}_{4}$ (irrigation at 80 percent of crop water requirement in black plastic mulched plots) which were 31.27 percent and 15.91 percent higher over surface irrigation treatment under unmulched and mulched conditions, respectively. The minimum per plant yield of $2.01 \mathrm{kgwas}$ obtained under unmulched cultivation with surface irrigation followed by use of plastic mulch in surface irrigated plots $(2.30 \mathrm{~kg})$.Increasing the volume of water from 80 percent to 100 percent of crop water requirement decreased the yield from 83.22 to $80.66 \mathrm{t} / \mathrm{ha}$ and from 88.99 to $86.66 \mathrm{t} / \mathrm{ha}$ in unmulched and mulched conditions, respectively. Use of plastic mulch also significant impact on crop yield. Use of the mulch alone increased the fruit yield by 6.93 percent and 14.59 percent in case of 80 percent of irrigation water supplied through drip and surface irrigation, respectively.

Higher yield under drip irrigation with favourable moisture is attributed to the higher uptake of nutrients and excellent soil-water relationship with higher oxygen concentration in the root zone (Gornat et al., 1973). Swarajyalakshmi et al., (2005) also reported the highest green chilli yield through drip method scheduled at 0.8 ET under black polythene mulch. Pattanaik et al., (2003) reasoned that the minimum yield under surface irrigation was due to the water stress during the critical growth period coupled with aeration problem due to application of excess of irrigation water and high weed infestation.

\section{Water use efficiency}

As evident from Table 5, drip irrigation with and without polyethylene mulch registered higher water use efficiency as compared to surface irrigation. The highest water use efficiency $\left(437.6 \mathrm{~kg} \mathrm{ha}^{-1} \mathrm{~mm}^{-1}\right.$ ) was recorded in treatment $\mathrm{T}_{8}$ (irrigation at 40 percent drip irrigation with black plastic mulch followed by $\mathrm{T}_{7}$. The minimum water use efficiency was observed for the surface irrigated plot without mulching (142.4 kg ha $\left.{ }^{-1} \mathrm{~mm}^{-1}\right)$, indicating excessive application of water. Table 5 also reveals that as the irrigation volume is increased from 40 to 100 percent of crop demand there was simultaneous reduction in water use efficiency both in mulched and unmulched plots. In un-mulched plots it showed reduction from 412.8 to $171.4 \mathrm{~kg} \mathrm{ha}^{-1} \mathrm{~mm}^{-1}$, whereas the reduction in mulched plots was from 437.6 to $184.2 \mathrm{~kg} \mathrm{ha}^{-1} \mathrm{~mm}^{-1}$. Higher yield and lower amount of applied water are the main reasons for increasing the water use efficiency indicating higher return per unit of applied water. Reduced amount of water through drip system during irrigation was helpful for achieving higher water use efficiency. These results are in conformity with the observations of Veeranna et al., (2001). Mulches help in better utilization of applied water by reducing the rate of water loss through evaporation from soil surface. Paul et al., (2013) also found the significant effect of black plastic mulch over drip irrigation alone on water use efficiency of capsicum as compared to unmulched soil.

The present study has indicated that Indira variety of capsicum produced with drip irrigation at $80 \%$ of crop water requirement and 40 micron black polyethylene mulch under naturally ventilated polyhouse in the agro climatic condition of Tarai region of Uttarakhand resulted into better plant morphological characters viz. plant height, fresh and dry weight of plant and root and fruit characters such as number of fruits per plant, average fruit weight, fruit length and diameter, polar \& lateral circumstances of fruit and total a yield of $89 \mathrm{t} / \mathrm{ha}$, the highest among all treatments. The combination of drip irrigation (80\% crop water requirement) and 
black plastic mulch (40 micron) increased the water use efficiency from 142 to 236 $\mathrm{kg} / \mathrm{ha} . \mathrm{mm}$.

\section{References}

Allen, R.G., Pereira, L.S., Raes, D. and Smith, M. 1998. Crop evapotranspiration guidelines for computing crop water requirements. FAO Irrigation and drainage paper 56. Food and Agriculture Organization, Rome.

Antony, E. and Singandhupe, R.B. 2004. Impact of drip and surface irrigation on growth yield and WUE of capsicum (Capsicum annum L.). Agricultural Water Management. 65,121-132

Bhatt, L., Rana, R., Uniyal, S.P. and Singh, V.P. 2011. Effect of mulch materials on vegetative characters, yield and economics of summer squash (Cucurbita pepo) under rainfed mid hill condition of Uttarakhand. Vegetable science 382, 165-168.

Choudhary, V.K. and Bhambri, M.C. 2012. Agro-economic potential of capsicum with drip irrigation and mulching. SAARC Journal of Agriculture, 10, 5160.

Gornat, B., Goldberg, D., Rimon, D. and Asher, B.J. 1973. The physiological effect of water quality and method of application on tomato, cucumber and pepper. Journal of American Society of Horticultural Science. 98, 202-205.

Jackson, M.L. 1967. Soil Chemical Analysis, Prentice Hall Pvt. Ltd., New Delhi, India. $498 \mathrm{p}$

Lodhi, A.S., Kaushal, A. and Singh, K.G. 2014. Impact of irrigation regimes on growth, yield and water use efficiency of sweet pepper. Indian Journal of Science and Technology. 7, 790-794.

Nadeem, M., Anjum, F.M., Khan, M.R., Saeed, M. and Riaz, A. 2011. Antioxidant potential of bell pepper
(Capsicum annum L.)- A Review. Pakistan Journal of Food Science. 21, 45-51.

Nagalakshmi, S., Palanisamy, D., Eswaran, S. and Sreenarayanan, V.V. 2002. Influence of plastic mulching on chilli yield and economics. South Indian Horticulture. 50, 262-265.

Olsen, S.R., Cole, C.V. and Dean, L.A. 1954. Estimation of available phosphorus in soil by extraction with sodium bicarbonate. In: Black, C.A. (Ed.). Methods of Soil Analysis. Part 2. American Society of Agronomy. Madison, USA. pp. 1044-1046

Pattanaik, S.K., Sahu, N.N., Pradhan, P.C. and Mohanty, M.K. 2003. Response of Banana to drip irrigation under different irrigation designs. Journal of agricultural Engineering. 40, 29-34.

Paul, J.C., Mishra, J.N., Pradhan, P.L. and Panigrahi, B. 2013. Effect of drip and surface irrigation on yield, water-useefficiency and economics of capsicum (capsicum annum L.) grown under mulch and non-mulch conditions in eastern coastal India. European Journal of Sustainable Development. 2, 99-108.

Pratt, P.F. 1965. Potassium. In: Methods of Soil Analysis, Vol. II. Chemical and Biological Properties. American Society of Agronomy. Madison, USA. pp.1023-1030

Sezen, S.M., Yazar, A. and Eker, S. 2006. Effect of drip irrigation regimes on Yield and quality of field grown bell pepper. Agricultural Water Management. 81, 115-131.

Sharp, R.E., Hasio, T.C. and Silk, W.K. 1990. Growth of maize primary root at low water potentials. II. Role of growth and deposition of hexoses and potassium in osmotic adjustment. Plant Physiology. 93, 1337-1346.

Singh, D.P., Anand, N. and Deshpande, A.A. 
1993. Improvement of bell pepper. In: Chadha, K. L., Kallo, G. (Eds.). 66 p

Singh, R., Kumar, S., Nangare, D.D. and Meena, M.S. 2009. Drip irrigation and black polyethylene mulch influence on growth, yield and water-use efficiency of tomato. African Journal of Agricultural Research. 4, 1427-1430.

Swarajyalakshmi, K.M., Reddy, D.M., Shivashankar, M., Babu, S. and Nageswara, R.P. 2005. Studies on response of chilli to different levels of drip irrigation and mulching as compared to basin method of irrigation. In: International conference on plasticulture and precision farming, New Delhi, India

Subbiah, B.V. and Asija, G.L. 1956. A rapid procedure for estimation of available nitrogen in acid soils. Current Science.
$25,259-260$

Veeranna, H.K., Khalak, A. and Sujin, G.M. 2001. Effect of fertigation and irrigation methods on yield, water and fertilizer use efficiency in chilli. South Indian journal of Horticulture. 49, 101-104.

Walkey, S.I. and Black, T.A. 1934. An examination of the degtjareff method for determining soil organic matter and a proposed modification of the chromic acid titration method Soil Science 37: 29-38

Wien, H.C., Minotti, P.L. and Grubinger, V.P. 1993. Polyethylene mulch stimulates early root growth and nutrient uptake of transplanted tomatoes. Journal of American Society of Horticultural Science. 118(2), 207-211.

\section{How to cite this article:}

Sajal Debbarma, Lalit Bhatt and Uniyal, S. P. 2019. Response of Bell Pepper (Capsicum annum L. var. grossum) to Drip Irrigation Levels and Black Plastic Mulch under Naturally Ventilated Polyhouse. Int.J.Curr.Microbiol.App.Sci. 8(10): 449-458.

doi: https://doi.org/10.20546/ijcmas.2019.810.048 